baf- $\odot$

Proceedings of the Berner

Altorientalisches

Forum

ISSN 2504-2076

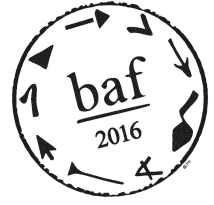

Abstract

Birchler Emery et al., Université de Genève

DOI: http://dx.doi.org/10.22012/baf.2016.06

\title{
The Bay of Kiladha Project (Argolid, Greece): Bridging East and West
}

The Bay of Kiladha Project is a joint research program between the University of Geneva, under the aegis of the Swiss School of Archaeology in Greece, and the Greek Ephorate of Underwater Antiquities. It aims at finding traces of prehistoric human activity in a small bay of the southern Argolid, Greece. The reason for choosing such a bay is linked to the presence, on its northeastern shore, of Franchthi Cave. This major prehistoric site was used, though not necessarily continuously, from at least 40,000 years ago, in the Upper Palaeolithic, to about 5,000 years ago, at the end of the Neolithic. For most of these 35,000 years, because of global sea-level change in prehistory, the Bay of Kiladha was in fact a small coastal plain. It is there, and on its shores, that the nomadic hunter-gatherers of the Upper Palaeolithic and Mesolithic periods found the resources they brought back to the cave. Later, the sedentary farmers of the Neolithic period, who used the cave for various activities, but not as a dwelling place, probably had their village there, where they could find open fields for agriculture and herding.

As it is now becoming clear that these sedentary farmers came from the Near East, and as the latest chronological evidence from Franchthi Cave points to an earlier beginning of the Neolithic period there than anywhere else in Greece, or even Europe, finding a submerged Early Neolithic village in the Bay of Kiladha would bring a wealth of information as to the dispersal of the Neolithic way of life, and individuals, from East to West.

Research currently focuses on two parts of the bay:

1) The Franchthi sector, close to Franchthi Cave. Investigations there by an American team looking for a submerged Neolithic village started in the late 1970s and early 1980s, but no conclusive evidence was found, and archaeological interest in the Bay of Kiladha came to a halt. Research was resumed in 2012 by the present team: a new bathymetric chart of the bay was made, and the same area was further investigated in 2013, using an experimental coring system, which yielded even more material evidence from the Neolithic period. In 2014, as the Bay of Kiladha Project was an integral part of the University of Geneva Terra Submersa Expedition in the eastern Argolic gulf, to study submerged prehistoric landscapes, geophysical measures revealed a mysterious layer in the vicinity of the cave, and in 2015 new techniques were used to explore the said layer: piston coring, by the University of Bern, and geoacoustic modelling, by the Université Libre de Bruxelles.

2) The Lambayanna sector, just a few hundred meters to the north of Franchthi Cave. During the Terra Submersa Expedition, underwater stone structures and finds, dating from the Early Bronze Age, were found there, and further investigation in 2015 revealed that they belonged to an Early Helladic II, or mid-third millennium BCE, fortified settlement. 